\title{
EFFECT OF THE ANATOMICAL STRUCTURE, WOOD PROPERTIES AND MACHINING CONDITIONS ON SURFACE ROUGHNESS OF WOOD
}

\author{
Rubén Laina ${ }^{1, \star}$, Alfredo Sanz-Lobera $^{2}$, Antonio Villasante ${ }^{3}$, Pablo López-Espí, \\ Jose Antonio Martínez-Rojas ${ }^{4}$, Jesús Alpuente ${ }^{4}$, Rocío Sánchez-Montero ${ }^{4}$, Santiago Vignote ${ }^{I}$
}

\begin{abstract}
The main aim is to test the influence of anatomical structure (grain direction and elements size), wood hardness and machining conditions on wood surface roughness. 180 samples defect-free were obtained from beech, oak and pine and processed with different machining methods (planning, sanding with 60 grit or sanding with 180 grit). Roughness, hardness, and anatomical structure were analysed using international methodologies. An analysis of variance of the data from all the samples with the four factors in the experimental design were performed. Results showed that machining processes and species are the factors that significantly affect surface roughness, as opposed to grain direction (plane of section and stylus-grain angle), which was only shown to be significant in some subgroups. Roughness parameters of samples sanded with 180 grit were lower in contrast to samples planned or sanded with 60 grit. Hardness was found to be the property of the wood that most clearly affects its final roughness, and makes it difficult to achieve better roughness results as the hardness increases.
\end{abstract}

Keywords: Fagus sylvatica, hardness, Pinus sylvestris, Quercus alba, roughness.

\section{INTRODUCTION}

The surface roughness of wood products depends on a number of factors related to the wood's anatomical structure and properties, the machining tools and the cutting parameters used. The wood properties that affect roughness are density, moisture content, texture and anatomical structure (Aguilera and Muñoz 2011, Magoss 2008, Gurau et al. 2005). The most important factors in the machining process are the type of tool, the cutting angles, the degree of sharpness, speed, and the magnitude of the vibration of the machine bench (Aguilera and Muñoz 2011, Magoss 2008).

The anisotropic nature of wood and the random character of the plane of section relative to sanding make it very difficult to correlate roughness with anatomical structure, although in the theoretical case of sanding with a high grit density, roughness would only depend on the structural and anatomical properties of the wood (Magoss 2008).

The surface quality of wood is an important property that influences other manufacturing processes such as glue bonding, finishing and even its durability (Richter et al. 1995). Even more importantly, roughness affects the aesthetic appeal of the product in terms of touch and appearance (Sandak and Negri 2005). 
Traditional methods of measuring surface roughness are based on the visual or tactile inspection of the surface, which although a very subjective and somewhat unreliable method, is still the most widely used in the timber industry. Different measuring standards for roughness are used in research. The most widespread method involves passing a stylus tip over the wood surface, which has limitations for industrial use, as its progress is slow and the results are laborious to interpret. To resolve these drawbacks, systems have been developed based on image analysis including laser probes, but these are currently very expensive, and must generally be checked against profilometers (Sandak and Tanaka 2003).

The research described in this work analyses the variability in the roughness of samples from three different species of wood because of anatomical difference (tracheid or vessel size) together with the influence of the plane of section. Experimental design also includes the stylus angle in relation to the grain direction, and finally, the difference between different wood machining processes according the most often process employed in Spain.

\section{MATERIALS AND METHODS}

To assess surface roughness a total of 180 defect-free samples were performed measuring $70 \mathrm{~mm}$ (direction of the grain) $\times 70 \mathrm{~mm} \times 15 \mathrm{~mm}$, from three species of very frequently used wood in Spain, and with widely differing anatomical features: Scots pine (Pinus sylvestris L.), beech (Fagus sylvatica L.) and American white oak (Quercus alba L.). Sixty samples were obtained from each species and divided in two groups according to the plane of section, 30 with the tangential surface and 30 with the radial surface, which were stabilised with the laboratory moisture $(11 \% \pm 1 \%)$.

Samples were taken randomly from each group of 30 samples from the same species and plane of section, and their surfaces were processed with different machining methods. Theses process are the most common employed in Spanish industry (Vignote and Martínez 2006). Samples were grouped and process as follows:

- $\quad$ Ten samples were planned in a machine with three blades with a tool angle of $47^{\circ}$, located on a cutter head with a diameter of $76 \mathrm{~mm}$, operating at $4500 \mathrm{rpm}$, with a feed rate of $6 \mathrm{~m} /$ min, a tooth pitch of $1,86 \mathrm{~mm}$ and a step height of $28,8 \mu \mathrm{m}$.

- $\quad$ Ten samples were sanded with a 60 grit manual belt sander (grit size between 250 and $300 \mu \mathrm{m}$ ), a sanding speed of $300 \mathrm{~m} / \mathrm{min}$, and sanding pressure of between 0,5 and $1 \mathrm{~kg} / \mathrm{cm}^{2}$ for 8 seconds, using a small oscillating movement. Although the contact pressure may differ between the series of experiments, its influence can be considered insignificant (Gurau et al. 2007). All the samples had been previously planned.

- $\quad$ Ten samples were sanded with a 180 grit manual vibrating sander (grit size between 63 and $90 \mu \mathrm{m}$ ), with a vibration of 20000 oscillations/min and sanding pressure between 0,3 and $0,6 \mathrm{~kg} / \mathrm{cm}^{2}$ for 8 seconds. All the samples had been previously planed and sanded with 60 .

Roughness was analysed using a contact PROFILTEST SM-7 profilometer with a radius of $5 \mu \mathrm{m}$ at the point. The apparatus assesses surface roughness parameters according to standard ISO-8503:2012, with a measuring capacity of up to $320 \mu \mathrm{m}$ and a resolution of $0,01 \mu \mathrm{m}$.

Roughness was measured in the central zone of the surface in each sample in two directions perpendicular to each other: parallel to grain and across to grain in the same way as Vitosyte et al. (2015). A total of 360 measurements (180 samples x 2 directions) were obtained. Each measurement is formed by 14 cutting lengths groups formed by 160 values than sum 2240 values for each measurement $35 \mathrm{~mm}$ length. They are downloaded to a spreadsheet on which the following roughness parameters are evaluated (ISO-4287,1998): 
- $\mathrm{Ra}=$ arithmetic mean of the absolute values of the profile

- $\mathrm{Rq}=$ square root of the mean of the squares of the profile readings

- $\mathrm{Ry}_{14}=$ mean of the differences between the maximum and minimum values of the 14 cutting lengths (ISO-8503,2012)

- $\mathrm{Rt}=$ maximum height between the end points of the profile of the total measurement length.

Some authors apply filters to the roughness data (Gurau et al. 2007, Vitosyte et al. 2015) in the belief that this allows the roughness due to anatomy to be isolated from the roughness due to machining. However these filters are not applied in this work, following the indications of Magoss (2008), who observed that this separation does not always give precise results. This study used an analysis of variance of the data from all the samples with the four factors in the experimental design: species, type of machining process, plane of section and stylus direction. The variances were compared within each group, which was defined by combining two factors or by grouping some non-significant factors. The level of significance applied was $5 \%$.

Each species was also characterised anatomically using material from the same batch of samples. The structure and properties of the specimens were first characterised by making a visual analysis of their main elements, and subsequently by preparing transversal sections of $20 \mu \mathrm{m}$ in thickness extracted with a microtome, which were mounted on slides and stained with safranin, then observed with an optical microscope and a magnification of $10 \mathrm{x}, 40 \mathrm{x}$ and 100x. The anatomical measurements of the main conducting elements were made with a previously calibrated viewer with a graduated microscope slide. Due to the substantial differences in the size and distribution of the conducting elements in the three species, the mean values of the diameters were obtained with the following procedures:

In Pinus sylvestris the total width of the ring was measured and divided between its component tracheid number (mean radial diameter). To estimate the mean tangential diameter, tracheid number was measured along a tangential length of $1000 \mu \mathrm{m}$. The two estimations were repeated in six areas taken at random.

In Fagus sylvatica (diffuse porous), the radial and tangential diameters were calculated for all the vessels located along the length of a growth ring in a band between two rays. The estimates were repeated in four areas taken at random.

In Quercus alba (ring porous), the radial and tangential diameters were calculated for all the earlywood vessels in the same ring located in a tangential band of $2000 \mu \mathrm{m}$. The radial and tangential diameters were then calculated for all the late vessels in a band located between two rays. The mean value was weighted based on the width of the early wood and the late wood in the sampling area. The estimates were repeated in four zones selected at random.

The anatomical results are expressed quantitatively by their mean and standard deviation.

Density was assessed by measuring sample dimensions with a precision calibre of $0,01 \mathrm{~mm}$, to determine the volume, weighed on a scale with a precision of $0,01 \mathrm{~g}$. Hardness was determined according to standard UNE 56534-77 (1997). It is the inverse of embed distance after pressing sample with a metal cylinder of $80 \mathrm{~mm}$ length and $30 \mathrm{~mm}$ diameter and a constant force of $100 \mathrm{~kg} / \mathrm{cm}$ for 5 seconds. 


\section{RESULTS AND DISCUSSION}

Table 1 and table 2 show a summary of the characterisation of the samples grouped by species, with the mean values of their main physical and visual characteristics.

Table 1. Characteristics of the samples.

\begin{tabular}{|c|c|c|c|c|c|c|c|}
\hline Species & Plane of section & Homogeneity & $\begin{array}{c}\text { Interval of } \\
\text { width of rings } \\
(\mathrm{mm})\end{array}$ & \multicolumn{2}{|c|}{$\begin{array}{c}\text { Wood density } \\
\left(\mathrm{g} / \mathrm{cm}^{3}\right)\end{array}$} & \multicolumn{2}{|c|}{ Hardness $\left(\mathrm{mm}^{-1}\right)$} \\
\hline \multirow[b]{2}{*}{ Pinus sylvestris } & Tangential & \multirow{2}{*}{$\begin{array}{l}\text { Major contrast between } \\
\text { early (light) and late } \\
\text { (dark) wood. } \\
\text { Sporadic resin canals. }\end{array}$} & 6,2 to 10 & \multirow[b]{2}{*}{$0,59(0,022)$} & \multirow[b]{2}{*}{ a } & $1,61(0,17)$ & \\
\hline & Radial & & $1,1-1,4$ & & & $1,77(0,47)$ & $\mathrm{a}$ \\
\hline \multirow[b]{2}{*}{ Fagus sylvatica } & Tangential & \multirow{2}{*}{$\begin{array}{l}\text { Minor contrast between } \\
\text { early and late wood, } \\
\text { barely visible to the } \\
\text { naked eye. } \\
\text { Numerous small woody } \\
\text { rays. }\end{array}$} & $11,1-33,3$ & \multirow[b]{2}{*}{$0,72(0,017)$} & \multirow[b]{2}{*}{$\mathrm{b}$} & $5,48(2,05)$ & \\
\hline & Radial & & $3,7-4,3$ & & & $4,84(0,65)$ & $\mathrm{b}$ \\
\hline \multirow[b]{2}{*}{ Quercus alba } & Tangential & \multirow[b]{2}{*}{$\begin{array}{l}\text { Major contrast between } \\
\text { early wood (visible } \\
\text { vessels) and late wood } \\
\text { (vessels not visible). } \\
\text { Long thick woody rays. }\end{array}$} & 7,1 to 9,0 & \multirow[b]{2}{*}{$0,71(0,010)$} & \multirow[b]{2}{*}{$\mathrm{b}$} & $7,08(1,66)$ & \\
\hline & Radial & & 1,6 to 0,4 & & & $3,85(2,17)$ & $\mathrm{b}$ \\
\hline
\end{tabular}

Standard deviations are shown in brackets for density and hardness. Values followed by a different lowercase letter between management treatments are significantly different. (Density $\mathrm{p}$ value $<0,0002$ ). Hardness has been analysed grouping per species ( $\mathrm{p}$ value $<0,0001$ ). Both analysis are according to Tukey's mean separation test.

Fagus sylvatica and Quercus alba had higher hardness values compared to Pinus sylvestris. The differences in density are lower than for hardness, but follow the same trend.

There is also a significant difference between the measurements of the anatomical elements of early wood of Quercus alba and the others groups analysed in table 2.

Table 2. Mean diameters of the main conducting anatomical elements.

\begin{tabular}{|l|c|c|c|}
\hline \multicolumn{1}{|c|}{ Species and plane of section } & Mean $(\mu \mathrm{m})$ & $\begin{array}{c}\text { Standard } \\
\text { deviation }\end{array}$ & $\begin{array}{c}\mathrm{N}^{\circ} \text { of } \\
\text { elements } \\
\text { measured }\end{array}$ \\
\hline Pinus sylvestris radial & $35,68 \mathrm{ab}$ & 2,102 & 302 \\
\hline Pinus sylvestris tangential & $26,46 \mathrm{a}$ & 0,922 & 227 \\
\hline Fagus sylvatica radial & $61,68 \mathrm{~b}$ & 19,175 & 179 \\
\hline Fagus sylvatica tangential & $41,32 \mathrm{ab}$ & 9,122 & 144 \\
\hline Quercus alba radial (early) & $276,23 \mathrm{c}$ & 68,78 & 23 \\
\hline Quercus alba tangential (early) & $226,67 \mathrm{c}$ & 62,31 & 23 \\
\hline Quercus alba radial (late) & $33,21 \mathrm{ab}$ & 6,86 & 53 \\
\hline Quercus alba tangential (late) & $27,80 \mathrm{ab}$ & 6,37 & 53 \\
\hline
\end{tabular}

Values followed by a different lowercase letter between management treatments are significantly different $(\mathrm{p}$ value $<0,0001)$ according to Tukey's mean separation test.

The results of the roughness meter readings have been grouped into those across to the grain (Table 3 and Figure 1) and those parallel to the grain (parallel to grain readings, Table 4 and Figure 2).

An analysis of variance of the results grouped according to direction of the stylus produced no significant differences. Vitosyte et al. (2015) observed that wood surface roughness in the case of across the grain was 1,46 times larger compared to that parallel to grain for tangential plane of section. This difference was observed after applying the Gaussian filter to the results (no filters were applied in 
the present work). Most of the articles cited in this discussion, however, -and which do not consider this point in their experimental designs- choose stylus direction across to the grain. The results are therefore shown separately to enable accurate comparisons with other authors.

Table 3. Mean values of the parameters of roughness across the grain. Standard deviations are shown in brackets.

\begin{tabular}{|c|c|c|c|c|c|}
\hline \multirow{2}{*}{ Parameter } & \multirow{2}{*}{ Species } & \multirow{2}{*}{$\begin{array}{l}\text { Planes of } \\
\text { section }\end{array}$} & \multicolumn{3}{|c|}{ Machining process $(\mu \mathrm{m})$} \\
\hline & & & Planning & Sanding 60 grit & Sanding 180 grit \\
\hline \multirow{6}{*}{$\mathrm{Ra}$} & \multirow{2}{*}{$\begin{array}{c}\text { Pinus } \\
\text { sylvestris }\end{array}$} & Tangential & $7,41(3,29)$ & $14,09(2,24)$ & $5,40(0,86)$ \\
\hline & & Radial & $6,92(2,33)$ & $14,84(2,41)$ & $7,40(3,90)$ \\
\hline & \multirow{2}{*}{$\begin{array}{c}\text { Fagus } \\
\text { sylvatica }\end{array}$} & Tangential & $5,82(1,47)$ & $10,64(2,48)$ & $7,83(4,40)$ \\
\hline & & Radial & $11,74(5,03)$ & $12,67(1,81)$ & $6,84(4,63)$ \\
\hline & \multirow{2}{*}{$\begin{array}{c}\text { Quercus } \\
\text { alba }\end{array}$} & Tangential & $11,27(3,45)$ & $11,94(1,65)$ & $10,12(2,5)$ \\
\hline & & Radial & $9,92(1,92)$ & $11,61(1,16)$ & $10,17(3,65)$ \\
\hline \multirow{6}{*}{$\mathrm{Rq}$} & \multirow{2}{*}{$\begin{array}{c}\text { Pinus } \\
\text { sylvestris }\end{array}$} & Tangential & $9,22(3,72)$ & $17,86(2,62)$ & $7,14(1,45)$ \\
\hline & & Radial & $8,69(2,65)$ & $19,20(3,06)$ & $9,23(4,42)$ \\
\hline & \multirow{2}{*}{$\begin{array}{c}\text { Fagus } \\
\text { sylvatica }\end{array}$} & Tangential & $7,37(1,70)$ & $13,58(2,83)$ & $9,65(4,94)$ \\
\hline & & Radial & $14,73(6,41)$ & $16,75(2,65)$ & $8,55(5,16)$ \\
\hline & \multirow{2}{*}{$\begin{array}{c}\text { Quercus } \\
\text { alba }\end{array}$} & Tangential & $16,97(4,88)$ & $16,71(2,36)$ & $15,71(2,7)$ \\
\hline & & Radial & $16,19(2,57)$ & $16,17(1,69)$ & $15,45(3,83)$ \\
\hline \multirow{6}{*}{$\mathrm{Ry}_{14}$} & \multirow{2}{*}{$\begin{array}{c}\text { Pinus } \\
\text { sylvestris }\end{array}$} & Tangential & $25,18(3,10)$ & $75,49(10,65)$ & $23,42(4,37)$ \\
\hline & & Radial & $28,58(3,49)$ & $86,63(12,03)$ & $26,86(18,75)$ \\
\hline & \multirow{2}{*}{$\begin{array}{c}\text { Fagus } \\
\text { sylvatica }\end{array}$} & Tangential & $27,89(1,37)$ & $59,27(7,81)$ & $22,00(16,46)$ \\
\hline & & Radial & $38,46(8,28)$ & $74,53(10,52)$ & $20,26(2,58)$ \\
\hline & \multirow{2}{*}{$\begin{array}{l}\text { Quercus } \\
\text { alba }\end{array}$} & Tangential & $57,79(16,70)$ & $78,34(9,10)$ & $53,28(13,64)$ \\
\hline & & Radial & $65,21(10,17)$ & $75,95(9,85)$ & $53,40(7,03)$ \\
\hline \multirow{6}{*}{ Rt } & \multirow{2}{*}{$\begin{array}{c}\text { Pinus } \\
\text { sylvestris }\end{array}$} & Tangential & $60,13(14,34)$ & $122,56(18,36)$ & $51,32(11,25)$ \\
\hline & & Radial & $66,43(19,25)$ & $137,34(22,51)$ & $59,73(22,71)$ \\
\hline & \multirow{2}{*}{$\begin{array}{c}\text { Fagus } \\
\text { sylvatica }\end{array}$} & Tangential & $55,76(14,01)$ & $109,59(16,77)$ & $53,84(23,84)$ \\
\hline & & Radial & $89,27(28,7)$ & $133,75(27,6)$ & $53,30(16,43)$ \\
\hline & \multirow{2}{*}{$\begin{array}{c}\text { Quercus } \\
\text { alba }\end{array}$} & Tangential & $125,63(33,71)$ & $136,92(19,36)$ & $119,18(11,62)$ \\
\hline & & Radial & $139,68(37,01)$ & $138,06(21,21)$ & $125,34(18,41)$ \\
\hline
\end{tabular}

The analysis of Ra variance of three factors (plane of section, machining and species) in the roughness parameters all coincided in showing as significant the factor machining process ( $\mathrm{p}$-value $<$ $0,0001)$ and the factor species ( $\mathrm{p}$-value $=0,006)$. The interaction between these two factors was also very significant ( $\mathrm{p}$-value $<0,0001)$.

The roughness of Fagus sylvatica and Pinus sylvestris was reduced in the samples sanded with 180 grit compared to those with 60 grit, similar to results were reported in Kilic et al. (2006).

Planning process produced significantly smoother roughness than the samples sanded with 60 grit in Pinus sylvestris and non-significant differences in Fagus sylvatica and Quercus alba. (Figure 1). Similarly to Kilic et al. (2006) results, sanding with 60 grit does not contribute any improvement to the wood roughness compared to previously planned wood, although it might be useful to remove knivesplanning defects.

An analysis of the results by species indicates that the significant factor affecting surface roughness for Pinus sylvestris is the factor machining process ( $p$-value $<0,0001$ ). In case of Fagus sylvatica was the plane of section the significant factor affecting roughness $(\mathrm{p}$-value $=0,004)$. However, the isolated analysis of Quercus alba showed no significance for any of the three design factors. Gurau et al. (2007) found a substantial difference for Ra due to the machining in Quercus robur between samples sanded 
with 60 grit to sanded with 120 grit. These authors applied previously a Gaussian filter to transform data.

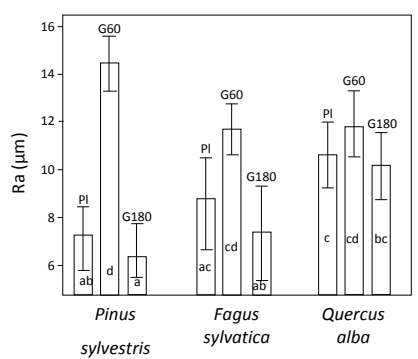

Figure 1. Values of across to grain Ra values for the different species and machining process. $\mathrm{Pl}=$ planed samples; $\mathrm{G} 60=$ samples sanded with 60 grit; $\mathrm{G} 180=$ samples sanded with 180 grit. The vertical segments indicate $95 \%$ confidence intervals. Lowercase letters indicate if groups are significantly different ( $\mathrm{p}$ value $<0,0001$ ) according to Tukey's mean separation test.

A comparative analysis of the Ra values between species and machining process (Figure 1) shows that the specimens of Pinus sylvestris machined with sanding with 180 grit and samples only planned showed lower values than same machining in Quercus alba. As well as a significant difference between 60 grit samples of Fagus sylvatica and Pinus sylvestris was encountered. If Ra is analysed inside each specimen group, a different in $\mathrm{Ra}$ is found between 60 grit and 180 grit in Pinus sylvestris group as well as Fagus sylvatica group.

It is important to note that the parameters $\mathrm{Ry}, \mathrm{Rq}$ and range showed that Quercus alba has a greater range of variation, coinciding with the results of Thoma et al. (2015). These authors compared Fagus sylvatica with Quercus petraea, another porous ring species in the Quercus genus, and found a significantly greater roughness for the machining process with sanding with 120 grit. Thoma et al. (2015) attributed the cause of this effect to the structure of the porous ring.

The analysis of variance of the parallel to grain readings, whose mean values and variances are shown in Table 4 and Figure 2, also reveal statistically significant results. The readings parallel to grain also reveal that the factor "machining" produces significantly different roughness values (p-value $<0,0001)$. It is worth noting that the parameter Ra for sanding with 60 grit was significantly higher than the other two machining processes ( $p$-value $<0,0001$ ). 
Table 4. Mean values of the parameters for parallel to grain roughness. Standard deviations are shown in brackets.

\begin{tabular}{|c|c|c|c|c|c|}
\hline \multirow{2}{*}{ Parameter } & \multirow{2}{*}{ Species } & \multirow{2}{*}{$\begin{array}{l}\text { Plane of } \\
\text { section }\end{array}$} & \multicolumn{3}{|c|}{ Machining process $(\mu \mathrm{m})$} \\
\hline & & & Planning & Sanding 60 & Sanding 180 \\
\hline \multirow{6}{*}{$\mathrm{Ra}$} & \multirow{2}{*}{$\begin{array}{c}\text { Pinus } \\
\text { sylvestris }\end{array}$} & Tangential & $5,88(2,39)$ & $12,16(2,45)$ & $15,38(8,24)$ \\
\hline & & Radial & $5,85(1,09)$ & $14,93(3,18)$ & $4,88(1,26)$ \\
\hline & \multirow{2}{*}{$\begin{array}{c}\text { Fagus } \\
\text { sylvatica }\end{array}$} & Tangential & $7,55(3,43)$ & $9,88(2,63)$ & $4,93(2,63)$ \\
\hline & & Radial & $8,72(5,26)$ & $12,42(1,98)$ & $11,86(7,46)$ \\
\hline & \multirow{2}{*}{$\begin{array}{c}\text { Quercus } \\
\text { alba }\end{array}$} & Tangential & $10,62(5,9)$ & $13,15(4,69)$ & $10,45(6,6)$ \\
\hline & & Radial & $7,97(6,32)$ & $12,54(1,93)$ & $9,85(2,76)$ \\
\hline \multirow{6}{*}{$\mathrm{Rq}$} & \multirow{2}{*}{$\begin{array}{c}\text { Pinus } \\
\text { sylvestris }\end{array}$} & Tangential & $7,39(2,77)$ & $15,77(3,05)$ & $19,08(9,39)$ \\
\hline & & Radial & $7,39(1,37)$ & $19,49(4,17)$ & $6,52(1,66)$ \\
\hline & \multirow{2}{*}{$\begin{array}{c}\text { Fagus } \\
\text { sylvatica }\end{array}$} & Tangential & $9,41(3,95)$ & $12,70(3,3)$ & $6,75(3,41)$ \\
\hline & & Radial & $11,05(6,04)$ & $16,39(3,44)$ & $14,73(8,49)$ \\
\hline & \multirow{2}{*}{$\begin{array}{c}\text { Quercus } \\
\text { alba }\end{array}$} & Tangential & $14,28(8,18)$ & $17,25(6,26)$ & $14,52(8,65)$ \\
\hline & & Radial & $10,33(7,72)$ & $16,74(2,55)$ & $12,98(4,15)$ \\
\hline \multirow{6}{*}{$\mathrm{Ry}_{14}$} & \multirow{2}{*}{$\begin{array}{c}\text { Pinus } \\
\text { sylvestris }\end{array}$} & Tangential & $20,44(1,58)$ & $47,30(9,38)$ & $24,79(3,07)$ \\
\hline & & Radial & $23,72(3,44)$ & $54,05(12,58)$ & $20,20(4,87)$ \\
\hline & \multirow{2}{*}{$\begin{array}{c}\text { Fagus } \\
\text { sylvatica }\end{array}$} & Tangential & $23,96(3,57)$ & $36,22(8,00)$ & $18,04(7,25)$ \\
\hline & & Radial & $29,14(7,86)$ & $52,75(13,39)$ & $19,04(4,52)$ \\
\hline & \multirow{2}{*}{$\begin{array}{l}\text { Quercus } \\
\text { alba }\end{array}$} & Tangential & $28,38(16,56)$ & $38,35(12,11)$ & $23,16(7,16)$ \\
\hline & & Radial & $23,98(7,68)$ & $40,18(9,57)$ & $22,27(7,02)$ \\
\hline \multirow{6}{*}{ Rt } & \multirow{2}{*}{$\begin{array}{c}\text { Pinus } \\
\text { sylvestris }\end{array}$} & Tangential & $48,78(10,72)$ & $103,57(21,98)$ & $100,143(30,76)$ \\
\hline & & Radial & $50,63(13,55)$ & $127,02(32,16)$ & $50,58(11,97)$ \\
\hline & \multirow{2}{*}{$\begin{array}{c}\text { Fagus } \\
\text { sylvatica }\end{array}$} & Tangential & $55,93(14,6)$ & $87,18(23,95)$ & $43,53(17,58)$ \\
\hline & & Radial & $66,73(26,16)$ & $118,77(33,83)$ & $74,86(27,01)$ \\
\hline & \multirow{2}{*}{$\begin{array}{c}\text { Quercus } \\
\text { alba }\end{array}$} & Tangential & $78,14(42,11)$ & $98,32(28,37)$ & $85,05(36,63)$ \\
\hline & & Radial & $63,17(32,73)$ & $107,68(23,29)$ & $70,18(25,48)$ \\
\hline
\end{tabular}

The factor "species" ceases to be significant in Ra analysis, although two interactions between this factor and the others are significant: machining, plane of section and specie interaction ( $p$-value < $0,0001)$ and plane of section-species ( $\mathrm{p}$-value $<0,0001$ ).

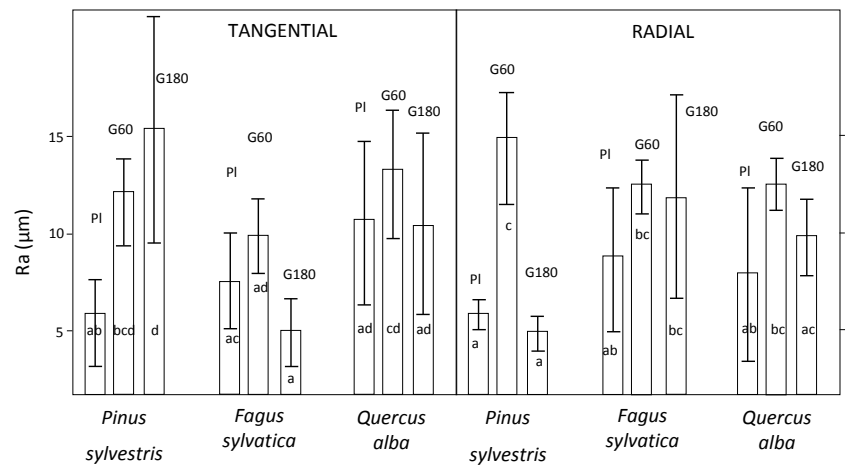

Figure 2. Values of parallel to grain Ra for the different species, machining process and surfaces.

$\mathrm{Pl}=$ planed samples; G60 = samples sanded with 60 grit; G180 = samples sanded with 180 grit. The vertical segments indicate $95 \%$ confidence intervals. Lowercase letters indicate if groups are significantly different ( $p$ value $<0,0001$ ) according to 
The most unusual and noteworthy result is the clear heterogeneity shown by the specimens of Pinus sylvestris for sanding with 180 grit compared to the other machining processes.

This particular finding may be explained by the action of rubbing with the sander, which -as it rests on a relatively flexible support- bites more deeply into areas of early wood. This effect is less pronounced in the radial surface as the rings are close together. In an industrial context it is not advisable to sand with grits of over 160 .

After the analysis of variance, a study was made of the relationship between the size of the anatomical elements and the roughness, and linear correlations were established between variables with high values of $\mathrm{R}^{2}$ (between 0,8 and 0,99 with some exceptions) in planed woods and woods sanded with 180 grit (Table 5). The results indicate that samples machined with a 60 -grit sander show greater roughness than is caused by their anatomy. Figure 3 shows the curves fitted to the Ra value and the size of the anatomical elements; the relation between anatomical size and roughness is higher in the best machined with a 180-grit sander.

Table 5. Values for the analysis of regression between the mean diameters of the main conducting elements and roughness.

\begin{tabular}{|c|c|c|c|c|c|}
\hline Parameter & Machined & R Pearson & $\mathrm{R}^{2}$ & $\mathrm{a}$ & $\mathrm{b}$ \\
\hline $\mathrm{Ra}$ & $\mathrm{Pl}$ & 0,692 & 0,479 & $0,045(0,128)$ & 5,95 \\
\hline $\mathrm{Ra}$ & $\mathrm{G} 60$ & $-0,516$ & 0,266 & $-0,022(0,295)$ & 14,02 \\
\hline $\mathrm{Ra}$ & $\mathrm{G} 180$ & 0,901 & 0,813 & $0,045(0,014)$ & 5,07 \\
\hline $\mathrm{Rq}$ & $\mathrm{Pl}$ & 0,894 & 0,799 & $0,100(0,016)$ & 5,75 \\
\hline $\mathrm{Rq}$ & $\mathrm{G} 60$ & $-0,193$ & 0,037 & $-0,010(0,713)$ & 17,31 \\
\hline $\mathrm{Rq}$ & $\mathrm{G} 180$ & 0,940 & 0,883 & $0,092(0,005)$ & 5,07 \\
\hline $\mathrm{Ry}_{14}$ & $\mathrm{P}$ & 0,997 & 0,993 & $0,449(<0,0001)$ & 11,64 \\
\hline $\mathrm{Ry}_{14}$ & $\mathrm{G} 60$ & 0,113 & 0,013 & $0,027(0,831)$ & 73,32 \\
\hline $\mathrm{Ry}_{14}$ & $\mathrm{G} 180$ & 0,907 & 0,822 & $0,378(0,013)$ & 8,90 \\
\hline $\mathrm{Rt}$ & $\mathrm{Pl}$ & 0,984 & 0,968 & $0,929(<0,0001)$ & 29,771 \\
\hline $\mathrm{Rt}$ & $\mathrm{G} 60$ & 0,570 & 0,324 & $0,172(0,238)$ & 118,63 \\
\hline $\mathrm{Rt}$ & $\mathrm{G} 180$ & 0,945 & 0,893 & $0,879(0,004)$ & 20,59 \\
\hline
\end{tabular}

$\mathrm{Pl}=$ planed samples; $\mathrm{G} 60=$ Samples sanded with 60 grit; $\mathrm{G} 180=$ Samples sanded with 180 grit. $\mathrm{a}$ and $\mathrm{b}$ are the parameters of the regression curve $(\mathrm{y}=\mathrm{ax}+\mathrm{b})$, where $\mathrm{y}=$ roughness; $\mathrm{x}=$ mean anatomical size. The $\mathrm{p}$-value are shown in brackets.

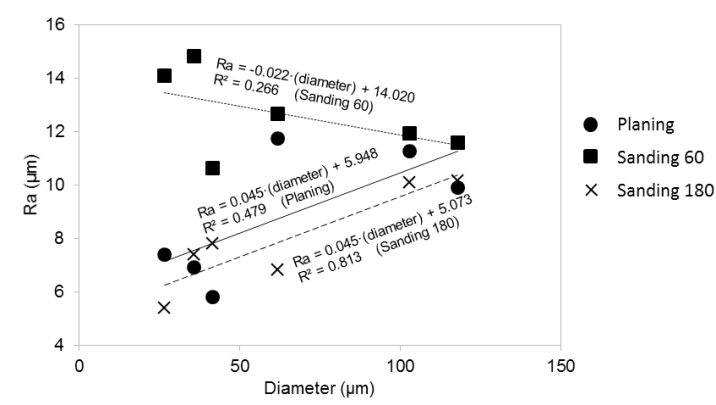

Figure 3. Relation between the mean size of the anatomical elements and Ra in the samples with the three types of machining process.

A new variable was built to analyse the relationship between hardness and the improvement in surface quality with sanding. This is defined as the quotient between the parameter Ra obtained with sanding with 60 grit and sanding with 180 grit (Ra60/Ra180). This variable was linearly related with 
the hardness value, as shown in Table 6 . The parameter Ra obtained with sanding with 60 grit produced higher values (between 1,05 and 3,06 times) than those obtained for sanding with 180 grit, except in the case of Pinus sylvestris as mentioned earlier.

Table 6. Relation between $\mathrm{Ra}_{60} / \mathrm{Ra}_{180}$ and hardness.

\begin{tabular}{|c|c|c|c|c|}
\hline \multirow{2}{*}{\multicolumn{2}{|c|}{ Species and angle }} & \multicolumn{2}{|c|}{$\mathrm{Ra}_{60} / \mathrm{Ra}_{180}$} & \multirow{3}{*}{$\begin{array}{c}\underset{\left(\mathrm{mm}^{-1}\right)}{\text { Hardness }} \\
1,61\end{array}$} \\
\hline & & \multirow{2}{*}{$\begin{array}{c}\begin{array}{c}\text { Across to } \\
\text { grain }\end{array} \\
2,61\end{array}$} & \multirow{2}{*}{$\begin{array}{c}\text { Parallel to grain } \\
0,79\end{array}$} & \\
\hline \multirow{2}{*}{$\begin{array}{l}\text { Pinus } \\
\text { sylvestris }\end{array}$} & Tangential & & & \\
\hline & Radial & 2,0 & 3,06 & 1,77 \\
\hline \multirow{2}{*}{$\begin{array}{l}\text { Fagus } \\
\text { sylvatica }\end{array}$} & Tangential & 1,36 & 2,0 & 5,48 \\
\hline & Radial & 1,85 & 1,05 & 4,84 \\
\hline \multirow{2}{*}{$\begin{array}{l}\text { Quercus } \\
\text { alba }\end{array}$} & Tangential & 1,18 & 1,26 & 7,08 \\
\hline & Radial & 1,14 & 1,27 & 3,85 \\
\hline
\end{tabular}

The regression analysis of hardness for the relation Ra60/Ra180 showed a slight inverse correlation between both variables. A correlation $\left(\mathrm{R}^{2}=0,59\right)$ is detected between the decrease in hardness and the reduction in roughness when only the transversal readings are considered (Figure 4$)$. The correlation is negligible for parallel to grain roughness $\left(\mathrm{R}^{2}<0,1\right)$.

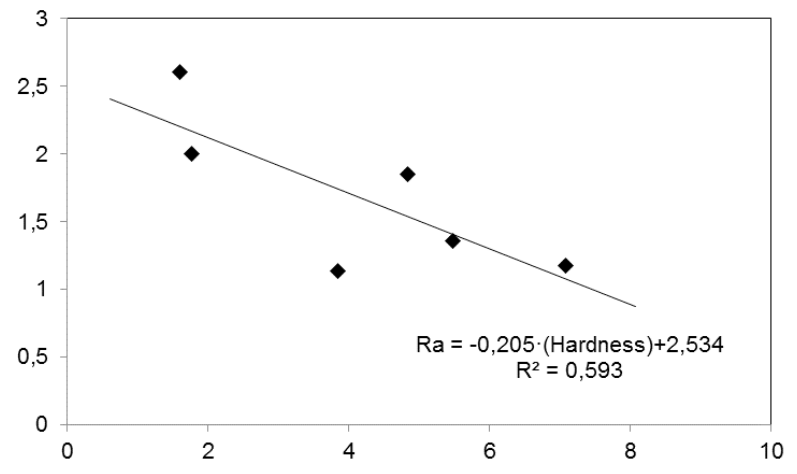

Figure 4. Relation between quotient Ra60/Ra180 and hardness.

\section{CONCLUSIONS}

Machining processes and species are the factors that significantly affect surface roughness, as opposed to the plane of section factor or the direction of the stylus tracing, which were only shown to be significant in some subgroups.

The sanding sequence used in this study shows that sanding with 60 grit produces higher or equal roughness values than planed process, indicating that the use of this type of sanding is uneconomical after a planning phase. This supports a system of first sanding with 180 grit after planning, and only changing to coarser grits when there are serious planning defects. Roughness is reduced with sanding with 180 grit, except in the parallel to grain readings of the tangential plane of Pinus sylvestris. The relation between the greater size of the anatomical elements and increased roughness is higher in sanding with 180 grit; that is, when there is less roughness. In contrast, this correlation was very weak for sanding with 60 grit. 
Hardness was found to be a property of the wood that clearly affects its final roughness, and makes it difficult to achieve better roughness results as the hardness increases.

\section{ACKNOWLEDGEMENTS}

This article is the result of the work in Project AGL2013-44631-P in the National R+D+i programme of the Ministry of Economy and Competitiveness, Spain.

\section{REFERENCES}

Aguilera, A.; Muñoz, H. 2011. Rugosidad superficial y potencia de corte en el cepillado de Acacia melanoxylon y Sequoia sempervirens. Maderas.Ciencia y Tecnología 13 (1):19-28.

Gurau, L.; Mansfield-Williams, H.; Irle, M. 2007. Separation of processing roughness from anatomical irregularities and fuzziness to evaluate the effect of grit size on sanded european oak. Forest Products Journal 57 (1/2):110.

Gurau, L.; Mansfield-Williams, H.; Irle, M. 2005. The influence of wood anatomy on evaluating the roughness of sanded solid wood. Journal of the Institute of Wood Science 17 (2):65-74.

ISO - 8503. 2012. Part 4: Method for the calibration of ISO surface profile comparators and for the determination of surface profile -- Stylus instrument procedure.

ISO - 4287. 1998. Geometrical Product Specifications (GPS), Surface Texture, Profile Method, Terms, Definitions and Surface Texture Parameters.

Kilic, M.;Hiziroglu, S.;Burdurlu, E. 2006. Effect of machining on surface roughness of wood. Building and Environment 41(8):1074-1078.

Magoss, E. 2008. General regularities of wood surface roughness. Acta Silv Lign Hung 4:81-93.

Richter, K.; Feist, W. C.; Knaebe, M. T. 1995. The effect of surface roughness on the performance of finishes. Part 1: roughness characterization and stain performance. Forest Products Journal 45(7/8):91-96.

Sandak, J.; Negri, M. 2005. Wood surface roughness-what is it. $17^{\text {th }}$ International Wood Machining Seminar, Rosenheim, Germany.

Sandak, J.; Tanaka, C. 2003. Evaluation of surface smoothness by laser displacement sensor 1: Effect of wood species. Journal of Wood Science 49(4):305-311.

Thoma, H.; Peri, L.; Lato, E. 2015. Evaluation of wood surface roughness depending on species characteristics. Maderas. Ciencia y Tecnología 17(2):285-292.

UNE 56534-77. 1997. Características físico-mecánicas de la madera. Determinación de la dureza.

Vignote, S.; Martínez, I.; 2006. Tecnología de la madera. Mundi Prensa Ed., Madrid Spain.

Vitosyte, J.; Ukvalbergenie, K.; Keturakis, G. 2015. Roughness of sanded wood surface: An impact of wood species, grain direction and grit size of abrasive material. Medžiagotyra 21(2):255-259. 